\title{
Myśl pedagogiczna św. Porfiriusza z Kafsokaliwii
}

\author{
Grzegorz Makal
}

Uniwersytet w Białymstoku, Katedra Teologii Prawosławnej, Polska ORCID: 0000-0003-3021-0036

makalgrzegorz1@gmail.com

G. Makal, The pedagogical thought of St. Porphyrios of Kafsokalivia, Elpis, 22 2020: 139-144.

\begin{abstract}
Saint Porphyrios (Bairaktaris) of Kafsokalivia (1906-1991) is one of the most famous contemporary Greek saints. He belonged to one of the most respected in Orthodoxy category of holy Elders, that is, spiritual fathers endowed with the charism of clairvoyance. As an experienced spiritual director, he passed on his pedagogical thought, which focuses on the purpose of Christian life - divinization, the parent's desire to become a saint and pass on holiness to his children not through discipline and pressure, but through God's grace, which acts as a parent seeks to sanctify. The Elder opposed unequivocally selfishness, seeing excessive praise as the cause of the poor spiritual development of the child. He emphasized the need to obtain and pass on to the child the humility which he identified with the natural state of man and the necessary condition for obtaining God's grace.

Streszczenie: Święty Porfiriusz (Bairaktaris) z Kafsokaliwii (1906-1991) jest jednym z najbardziej znanych współczesnych świętych greckich. Należał do jednej z najbardziej szanowanych w prawosławiu kategorii świętych Starców, czyli ojców duchowych obdarzonych charyzmatem prozorliwości. Jako doświadczony kierownik duchowy przekazał swoją myśl pedagogiczną, która skupia się na celu życia chrześcijanina - przebóstwieniu, dążeniu rodzica do stania się świętym i przekazania świętości swoim dzieciom nie poprzez dyscyplinowanie i wywieranie presji, ale przez łaskę Bożą, która działa, gdy rodzic stara się uświęcić. Starzec przeciwstawiał się jednoznacznie egoizmowi, upatrując w nadmiernych pochwałach przyczyny złego rozwoju duchowego dziecka. Podkreślał potrzebę zdobycia i przekazania dziecku pokory, którą utożsamiał z naturalnym stanem człowieka i warunkiem koniecznym do zdobycia łaski Bożej.
\end{abstract}

Keywords: Porphyrios of Kafsokalivia, Orthodox upbringing, sainthood, humility, egoism

Słowa kluczowe: Porfiriusz z Kafsokaliwii, prawosławne wychowanie, uświęcenie, pokora, egoizm

W Cerkwi prawosławnej mamy do czynienia z wieloma kategoriami świętych. Wśród nich szczególnym zainteresowaniem cieszą się święci Starcy (gr. Гépovtas), czyli przewodnicy duchowi obdarzeni darem prozorliwościl, dzięki któremu bardzo skutecznie prowadzą swoich uczniów w drodze duchowej. W dwudziestym wieku praktycznie każdy kraj, w którym jest obecne prawosławie, posiadał jednego lub kilka takich postaci. Niektóre spośród nich zostały już kanonizowane ${ }^{2}$. W Grecji, ze względu na nieprzerwaną tradycję prawosławną sięgającą czasów apostolskich oraz na sąsiedztwo Góry Athos ${ }^{3}$, liczba świętych

\footnotetext{
Grecka literatura patrystyczna wyróżnia trzy stadia tego charyzmatu uwarunkowane stopniem doskonałości duchowej świętego: rozróżnianie

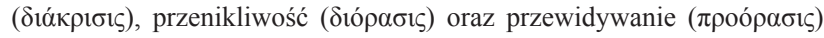
(zob. św. Jan Klimak, Drabina raju (2011), 717B, s.142). Za tradycyjną przyjmuje się definicję św. Jana Klimaka, który pisze, że rozróżnianie

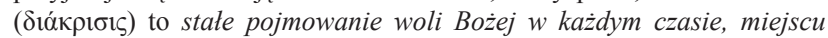
$i$ każdej okoliczności; mieści się ono jedynie w czystym sercu, ciele $i w$ czystych ustach (Drabina raju, 1013A, s. 257). Osoby, które osiągnęły doskonałość życia duchowego i zostały obdarzone tym charyzmatem, nie tylko znają samego siebie i rozróżniają dobro od zła, ale oświecone przez Boga widzą wnętrza innych ludzi oraz prawdziwą naturę otaczającego nas świata. Są w stanie przewidywać przyszłość ( $\pi \rho \circ o$ ó $\alpha \sigma i \varsigma)$ oraz mówić o rzeczach dawno minionych oraz ukrytych.

2 M.in. św. Amfilochiusz Poczajowski (+1971, Ukraina), św. Justyn Popović (+1979, Serbia), św. Sofroniusz Sacharow (+1993, Rosja - Anglia), św. Gabriel Urgebadze (+1995, Gruzja), św. Kleopa Ilje (+1998, Rumu-

3 Góra Athos, zwana też Świętą Górą (gr. Ayıv 'O $\rho \circ$ ), to położony w północnej Grecji półwysep z masywem górskim, posiadający status autonomicznego okręgu administracyjnego, zamieszkiwany tylko przez
} nia).
Starców działających w dwudziestym wieku jest znaczna ${ }^{4}$. Jednym z najbardziej znanych takich świętych jest św. Porfiriusz z Kafsokaliwii 5 .

prawosławnych mnichów, skupionych wokół dwudziestu monasterów. Tradycyjny monastycyzm i praktyka ascetyczno-modlitewna Athosu, dokąd wstęp mają tylko mężczyźni, utrzymywane są co najmniej od IX wieku. Tak długa i nieprzerwana ciągłość tradycji sprawia, że Święta Góra cieszy się szczególnym szacunkiem i autorytetem wśród prawosławnych na całym świecie.

4 M.in. św. Nektariusz z Eginy (+1920), św. Daniel z Katunakia (+1929), św. Mikołaj Planas $(+1932)$, św. Hieronim z Simonopetra $(+1957)$, św. Józef Hezychasta $(+1958)$, św. Jerzy Karslidis $(+1959)$, św. Amfilochiusz Makris $(+1970)$, św. Jakub Tsalikis $(+1991)$, św. Paisjusz Hagioryta (+1994), św. Efrem z Katunakia $(+1998)$ oraz oczekujący jeszcze na kanonizację, o. Filoteusz Zerwakos $(+1980)$, o. Epifaniusz Theodoropoulos (+1989), m. Gabriela Papagianni (+1992), m. Makaria z Nea Makri $(+1999)$ i inni.

5 Święty Porfiriusz z Kafsokaliwii (świeckie imię Ewangelos Bairaktaris) urodził się w 1906 roku na wyspie Eubea w Grecji. W wieku kilkunastu lat potajemnie udał się na Górę Athos (patrz przyp. poniżej) i zamieszkał w skicie Św. Trójcy znanym pod nazwą Kafsokaliwia, gdzie został mnichem. Po kilku latach w cudowny sposób otrzymał charyzmat widzenia, który pozwalał mu, dzięki łasce Bożej, widzieć wnętrza ludzi, ich myśli, przeszłość i przyszłość w sposób nieograniczony odległością. Następnie, z powodu choroby, musiał opuścić Athos i wrócił na Eubeę, gdzie został wyświęcony na prezbitera przez Porfiriusza III, arcybiskupa Synaju. Do 1940 roku niósł posługę spowiednika na Eubei, zaś po wybuchu II wojny światowej zaczął pracować jako kapelan Polikliniki Ateńskiej, gdzie pozostał aż do 1970 roku. Po przejściu na emeryturę poświęcił się realizacji idei wybudowania monasteru, co ostatecznie udało mu się dokonać zakładając wspólnotę w Milesi w Attyce. Latem 1991 roku wyjechał na Athos, do Kafsokaliwii, w której został mnichem i 2 grudnia zasnął w Panu. Ze względu na liczne świadectwa jego cudów, 
Nie posiadał wykształcenia, ani nie pochodził ze znacznego rodu, jednak ustawiały się do niego kolejki osób z całego świata, prostych i intelektualistów, zwykłych rolników, ale też inżynierów, lekarzy, astrofizyków i innych naukowców, których zadziwił swoim darem prozorliwości i których kierował w drodze duchowej. Pomimo rosnącej popularności w Grecji i krajach tradycyjnie prawosławnych (Rosja, Rumunia, Bałkany), osoba św. Porfiriusza nie doczekała się jeszcze naukowej publikacji na swój temat w języku polskim. Jego posługa spowiednika i kierownika duchowego setek, czy nawet tysięcy rodzin sprawia, że pierwszym tematem, który potrzebuje szczególnej uwagi, jest jego myśl pedagogiczna.

Osoba św. Porfiriusza jest obiektem licznych publikacji oraz konferencji naukowych głównie w języku greckim $^{6}$. W języku polskim kilka informacji o św. Porfiriuszu można znaleźć w dwóch pozycjach (Atanazy, metr., 2016, Chatzinikolaou, 2013), lecz noszą one charakter bardziej hagiograficzny lub biograficzny. Na uwagę zasługuje też tłumaczenie rosyjskiego przekładu antologii myśli św. Porfiriusza $O$ dzieciach $i$ młodzieży $y^{7}$, jednak najpełniejszy materiał do analizy stanowi książkowe wydanie wypowiedzi świętego spisanych z nagrań i notatek, pt. Bíos $\kappa \alpha l ~ \lambda o ́ \gamma o l^{8}$. Publikacja ta doczekała się w Grecji już szesnastu edycji, w tym trzech nowych wydań $(2003,2006,2015)$ i trzynastu wznowień oraz została przetłumaczona na dwadzieścia cztery języki (stan na 2019 rok). Już tylko ten fakt, stanowiący dowód rosnącego zainteresowania życiem i nauczaniem świętego, może stanowić powód do podjęcia badań nad tym dziełem. Dodatkowym atutem jest niedawno opublikowany polski przekład, który w krótkim czasie doczekał się dwóch wydań ${ }^{9}$. Unikalność tego źródła tłumaczy się też narracją w pierwszej osobie, co nadaje mu charakter autobiografii - dość rzadko spotykanego gatunku w hagiografii prawosławnej.

Publikacja została podzielona w oryginale na część biograficzną oraz część z nauczaniem świętego, podzielonym na tematyczne rozdziały. Mimo wyodrębnienia w tej książce rozdziału „O wychowywaniu dzieci”10, treść w nim zawarta nie posiada systematyzacji. Poza tym informacje o wychowaniu i rozwoju duchowym dziecka są zawarte nie tylko w tym jednym rozdziale. Materiały zawarte w tej pozycji będą stanowiły główne źródło niniejszej pracy, uzupełnione o inne dostępne materiały tłumaczone $\mathrm{z}$ języka greckiego.

$$
* * *
$$

$\mathrm{Na}$ podstawie dostępnych materiałów nie można stwierdzić, aby św. Porfiriusz definiował cel wychowania

27 listopada 2013 roku Patriarchat Konstantynopola ogłosił go świętym (dzień liturgicznego wspomnienia - 2 grudnia).

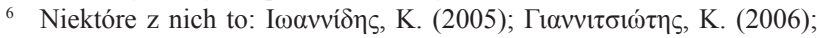

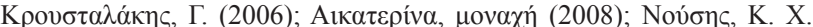

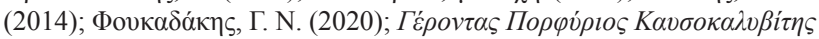

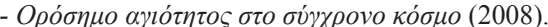

Święty Starzec Porfiriusz Kavsokalybita - O dzieciach i młodzieży (2016).

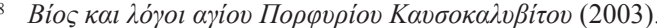

9 Święty Starzec Porfiriusz (2020).

10 Święty Starzec Porfiriusz (2020), s. 245-264 dziecka w jakiś szczególny sposób. W wielu miejscach natomiast podkreśla, jaki jest cel życia człowieka, niezależnie od jego wieku. W jego testamencie duchowym, który podyktował tuż przed śmiercią, czytamy: Zawsze będę życzył moim duchowym dzieciom, żeby pokochały Boga, Który jest wszystkim. By uczynit nas godnymi wejścia do Jego ziemskiej, niestworzonej Cerkwi. Bo to tutaj powinniśmy zaczynać (Św. Starzec Porfiriusz, 2020, s. 115).

Miłość do Boga, potrzeba zdobycia boskiego erosu, stanowi główny motyw nauczania św. Porfiriusza. W kontekście procesu wychowawczego należy zwrócić uwagę na rozróżnienie, jakie daje w znaczeniu miłości ziemskiej i miłości Bożej. Inne miłości osiagaja stan nasycenia. Mitość Chrystusa nie ma stanu nasycenia. Miłość doczesna (...) stopniowo gaśnie, podczas gdy Boża wciąż rośnie i się pogłębia. Każda inna miłość może doprowadzić człowieka do rozpaczy (Św. Starzec Porfiriusz, 2020, s. 134). (...) zwykła miłość, może czasem szkodzić (Św. Starzec Porfiriusz, 2020, s. 234).

Święty Porfiriusz zwraca uwage na to, że nawet największa miłość, czy to romantyczna, czy cielesna, czy nawet rodzicielska, pozbawiona aspektu Boga pozostaje skończona, ograniczona. Maksymalizm charakteryzujący mnichów, którzy wyrzekli się świata marnego i złudnego, którzy rodziców i braci znienawidzili bez nienawiści ${ }^{11}$, polega też na poszukiwaniu najdalszego punktu odniesienia, czyli wieczności. Doczesność, nawet przy nadaniu jej najwyższych pobudek moralnych, pozostaje skończona w czasie i dlatego święty Porfiriusz, jako mnich realizujący ideał całkowitego poświęcenia się Bogu, odrzuca ją, jako tę gorszą i nie przynoszącą ostatecznego, a więc i prawdziwie pozytywnego efektu: Miłość w Chrystusie. To ona prawdziwie pomaga. Tak dtugo, jak będziecie kochać swoje dzieci ludzka miłościa, która czesto bywa chora, tak dtugo będa zagubione, a ich zachowanie antagonistyczne (Św. Starzec Porfiriusz, 2020, s. 255).

Wejście do wieczności dla św. Porfiriusza oznacza wejście do Cerkwi, którą stanowia trzy osoby Trójcy Świętej (Św. Starzec Porfiriusz, 2020, s. 120). Wejście do Cerkwi ma oczywiście charakter chrystocentryczny, gdyż Chrystus jest Głową Cerkwi [Kol 1,18]. Bóg w swojej bezgranicznej miłości zjednoczył nas ponownie ze swoja Cerkwia w osobie Chrystusa. Wchodzac do Cerkwi niestworzonej, przychodzimy do Chrystusa, wchodzimy do niestworzonego. (...) jesteśmy wzywani do tego, by stać się niestworzonymi dzięki łasce, by stać się uczestnikami boskich energii, by wejść do misterium boskości, by wyjść poza styl życia tego świata, by obumart nasz ,, stary człowiek” [zob. Kol 3,9; Rz 6,6; Ef 4,22] i abyśmy zostali przebóstwieni. Gdy żyjemy w Cerkwi, żyjemy Chrystusem. Cerkiew i Chrystus sa jednym (Św. Starzec Porfiriusz, 2020, s. 121).

Temat przemiany, przebóstwienia boskimi energiami jako celu życia człowieka jest charakterystyczny dla teologii prawosławnej ${ }^{12}$ i dobrze opisany przez badaczy palami-

\footnotetext{
1 Zob. św. Symeon Nowy Teolog, Hymn VIII, 12-15, Sources Chrétiennes, 156, 214.

12 „Celem ostatecznym jest zjednoczenie z Bogiem lub przebóstwienie theosis Ojców greckich” Łosski, W. (1989) s. 7; por. „celem chrześcijani-
} 
zmu i hezychazmu, zatem nie ma potrzeby, aby skupiać się na jego aspekcie historycznym. Kluczowym pojęciem do dalszej analizy będzie świętość i uświęcanie się. W swoim testamencie święty Porfiriusz zawarł takie zdanie: Zawsze starałem się, z pomoca łaski Bożej, zbliżać się do Boga (Św. Starzec Porfiriusz, 2020, s. 115). Zbliżanie się do Boga, poznawanie Boga w teologii prawosławnej oznacza tradycyjnie uświęcanie się i przebóstwienie (Meyendorff, J., 1984, s. 181). To pojęcie, najczęściej zamieniane przez świętego na bardziej dynamiczne znaczeniowo „stawanie się świętym" jest, obok miłości Bożej, najczęściej stosowanym przez niego terminem w kontekście wychowania dziecka. Skoro celem życia człowieka jest stanie się świętym (poznanie Boga, przebóstwienie), to celem wychowania dziecka jest jak najlepsze wprowadzenie go w ten proces i ułatwienie mu jego kontynuowania.

Zgodnie z obserwacją św. Porfiriusza proces wychowania dziecka jest bezpośrednio związany ze stopniem świętości jego rodziców. Tym, co zbawia i ksztattuje dobre dzieci, jest życie domowe rodziców. Rodzice powinni oddać się miłości Bożej, stać się święci wobec dzieci. Jeśli rodzice nie zaczna się uświęcać (...), będa popetniać straszne błędy i przekazywać dalej zło, które maja w sobie. Starzec Porfiriusz cały ciężar odpowiedzialności za rozwój dziecka przenosi na stan duchowy jego rodziców i to od momentu poczęcia, gdyż od rodziców zależy, z jakiego poziomu dziecko zacznie swoje życie duchowe. Wychowanie dziecka zaczyna się od momentu jego poczęcia (...) Co tylko odczuwa mama, smutek, ból, stres i tak dalej, przeżywa té płód. Jeżeli matka nie chce tego dziecka, jeśli go nie kocha, ono to odczuwa $i$ w jego duszyczce tworza się rany, które będa mu towarzyszyć przez całe jego życie. Nie dochodzi do tego, jeśli uczucia matki sa święte. (...) Matka powinna w okresie ciaży (...) żyć świętym życiem. W ten sposób poświęca się dla płodu, żeby jej dziecko było bardziej święte, by na samym początku otrzymało dobre podstawy. Prawdziwym poświęceniem rodziców dla ich jeszcze nienarodzonego dziecka jest zatem uświęcanie się, zwłaszcza w zakresie ich relacji między sobą. Rodzice sa w petni odpowiedzialni za to, że ich dziecko nie ma poczucia bezpieczeństwa $i$ jest petne lęków. Już w tonie matki, przez złe relacje między rodzicami, tworza sie $w$ nim te wszystkie urazy psychiczne i problemy psychologiczne (Św. Starzec Porfiriusz, 2020, s. 248). Gdy rodzice źle odnosza się do siebie, rania swoje dzieci, które traca sity i ochote do tego, by się rozwijać (Św. Starzec Porfiriusz, 2020, s. 247).

Sposobem na uleczenie relacji między małżonkami jest pozytywna metoda walki z namiętnościami propagowana przez Starca Porfiriusza. Zamiast bezpośrednio walczyć $\mathrm{z}$ negatywnymi emocjami w małżeństwie, należy w chwilach walki duchowej „uciekać do przodu”, czyli nawiązywać kontakt z Chrystusem, najlepiej poprzez modlitwę Jezusową. Zamiast zajmować się namiętnościami, zwróćcie się ku miłości Chrystusa (Św. Starzec Porfiriusz,

na jest osiągnięciem błogosławionego stanu przebóstwienia, które tożsa-

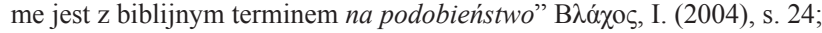
por. „ostatecznym celem chrześcijaństwa jest przebóstwienie człowieka” Larchet, J-C. (2013), s. 5.
2020, s. 185). W momencie, w którym wasza dusza musi walczyć, wołajcie: „Panie Jezu Chryste, zmiłuj się nade mna" (Św. Starzec Porfiriusz, 2020, s. 189). Taki zwrot, zwłaszcza w momentach nieoczekiwanych i prowokujących gwałtowną reakcję, jest według Starca możliwy tylko dzięki obecności łaski Bożej: Żeby to się wam udało, musi was oświecić łaska Boża (Tamże). Aby do tego doszło, taska Boża musi wptynać na dusze rodziców. Nikt nie staje się świętym sam z siebie (Św. Starzec Porfiriusz, 2020, s. 255). Bez łaski Bożej nie ma możliwości prowadzenia walki duchowej. Łaskę traci się przez egoizm lub gniew na kogoś, nawet tylko na poziomie myśli lub emocji: Najmniejsze nawet niezadowolenie z drugiego człowieka ma wpływ na wasza duszę i uniemożliwia wam modlitwę. Duch Święty, gdy zastaje duszę $w$ takim stanie, nie śmie się zbliżyć (Św. Starzec Porfiriusz, 2020, s. 151). W życiu duchowym nie ma stanu neutralnego. Jeśli popełniamy błąd i grzeszymy, to tak naprawdę wybieramy tego, który stoi za złem, czyli diabła. Św. Porfiriusz przestrzega: Nie dawajmy diabłu prawa do nas, czyli nie zachowujmy $w$ sobie ani jednej myśli wyrażającej uraz, pretensję, ani jednej myśli nacechowanej egoizmem, by szatan nie znalazł w nas okna dla siebie. Okno to prawo do nas. Gdy oddalasz się od Boga, jesteś w niebezpieczeństwie, bo szatan znajduje cię ,,pustym” i zaczyna tobą rządzić (Św. Starzec Porfiriusz, 2020, s. 190). Starzec Porfiriusz przedstawia w tym miejscu interpretację grzechu, jako wolitywnego działania przekazującego diabłu prawo do człowieka w takim zakresie, w jakim ten mu ulega czyniąc zło, nawet jeśli odbywa się to tylko w myślach ${ }^{13}$. Święty stawia znak równości między takimi myślami i grzechem, nazywając je ,niepowodzeniami”, zgodnie z etymologią greckiego terminu $\alpha \mu \alpha \rho \tau i ́ \alpha$ (grzech) oznaczającego „nietrafienie do celu, niewycelowanie”. Takie pojmowanie grzechu, jako ,źle wycelowanego” działania, którego efektem nie jest „utrata zasługi”, ale oddanie praw do swojej wolności szatanowi, charakteryzuje prawosławne nauczanie ${ }^{14}$. Dobrym przykładem zastosowania tej teologii w praktyce, jest jego reakcja na widok dziewczyny, która szła ubrana w wyzywający, jak na lata siedemdziesiąte, strój: Nie osądzajcie ludzi po tym, jak wyglądaja na zewnatrz. Ta dziewczyna, która widzicie posiada cudowna duszę! Posiada dynamizm w duszy. To, że teraz prowokuje swoim wygladem, jest spowodowane siła jej duszy. Wyobraźcie sobie, co się stanie, gdy ta dziewczyna pozna Chrystusa. Z pewnościa zajdzie wówczas bardzo

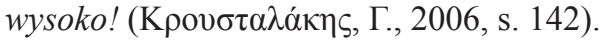

Kolejnym elementem, który odgrywa rolę w wychowaniu, jest według św. Porfiriusza nadopiekuńczość rodziców, którą nazywa on wprost presją i przymusem wywieranym na dziecku: Matki, które bez przerwy ślęczą nad swoimi dziećmi i wywierają na nie duża presję, czyli takie, które sa nadopiekuńcze, ponosza porażke w swoim dziele. (...) Jeśli ciagle stoisz dzieciom nad głowa, to się zbuntu-

\footnotetext{
Identyczną w założeniach, ale bardziej rozbudowaną interpretację można znaleźć u innego współczesnego Starca, św. Paisjusza Hagioryty

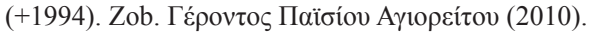

14 Zob. Łosski, W. (1989) s. 176-177. Por. Bazyli Wielki, św., O tym, że Bóg nie jest sprawca zła [w:] Bóg i zło (2004), ss. 46-49.
} 
ja. Nabiora gnuśności, chęci dogadzania sobie i raczej nie będzie im się później wiodło. Efektem nadopiekuńczości jest niedojrzałość dzieci (Św. Starzec Porfiriusz, 2020, s. 251). Formalnie pobożne życie rodziców, modlitwa, a nawet dobre wzajemne relacje między rodzicami może okazać się niewystarczające, zwłaszcza w okresie dojrzewania dziecka. Nieumiejętnie stosowana zachęta motywowana egoizmem zamienia się $\mathrm{w}$ przymus, presję, która prowokuje bunt, sprzeciw dziecka. Starzec miał do czynienia $\mathrm{z}$ wieloma zbuntowanymi nastolatkami, a także $\mathrm{z}$ rodzicami takich osób. Widział efekty źle pojmowanej roli religii w życiu człowieka i dlatego przestrzegał: Nie wystarczy, że rodzice będa pobożni. (...) Nie moge wywierać na nie zbyt dużej presji. Możemy odstraszyć, odegnać, odstręczyć dzieci od Chrystusa, jeśli wypetniamy obowiazki religijne z egoizmem. Dzieci nie potrzebuja presji. Dobrze, jeśli czytacie im Pismo Święte. Jeśli jednak któreś nie chce, zostawcie je w spokoju. (...) Nie zmuszajcie ich do chodzenia $z$ wami do cerkwi (Św. Starzec Porfiriusz, 2020, s. 256). Rodzicom nastolatka, który zaczął obracać się w złym towarzystwie i wracać późno w nocy, Starzec poradził: Teraz, w tym okresie nic mu nie mówcie. Ukrywajcie swoja „pobożność”. Nie prowokujcie go. W tej chwili jest jakby tak, że wy jesteście ubrani w wasze najlepsze, wyjściowe

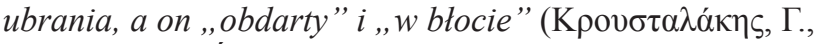
2006, s. 143). Święty Porfiriusz bynajmniej nie namawia do braku działań wobec dzieci lub do wyłączenia rodziców z procesu wychowania. Dzięki darowi prozorliwości święty widział, że nie wystarczy zwykła troska lub „normalna” miłość rodziców, by dziecko rozwijało się prawidłowo psychicznie i duchowo: Matka przenosi na dziecko caty swój stres związany z myśleniem o jego życiu, jego zdrowiu, jego rozwoju, nawet jeśli mu o tym nie mówi i nie wyraża tego, co przeżywa w środku. Taka mitość, czyli zwykta mitość, może czasem szkodzić. Jednak nie dzieje się tak z mitościa Chrystusowa, której towarzysza modlitwa i święte życie. Taka miłość robi z czlowieka świętego, wycisza go, gdyż mitościq jest Bóg (Św. Starzec Porfiriusz, 2020, s. 234). Matka nie może ograniczać się tylko do fizycznego przytulenia swojego dziecka, ale powinna ćwiczyć się $w d u-$ chowym przytulaniu przez modlitwę. Gdy skrycie i goraco modli się za swoje dziecko, wówczas ono czuje w duszy niewytlumaczalne dla siebie przytulenie, które przyciaga go do matki (Św. Starzec Porfiriusz, 2020, s. 250).

Modlitwa rodziców jest według Starca najlepszym sposobem rozwiązywania problemów z dziećmi. Módl się, a kiedy trzeba, mów do dzieci z mitościa. Módl się za nie więcej i mów do nich mniej. Dużo modlitwy i mało stów (...) Lepiej jest przemawiać sekretnie do serca rozmówców niż do ich uszu (...) Przemawiaj do nich przez modlitwę. To, co chcesz im powiedzieć, mów do Boga, a Bóg powie to w ich wnętrzu (...) powinnaś mówić o swoich dzieciach Bogu. Mów tak: „Panie Jezu Chryste, oświeć moje dzieci (...) Ty mi je dateś, ale jestem staba, nie potrafie ich nauczyć, dlatego proszę Cię, oświeć je” (...) Ideatem jest, gdy matka mówi do Boga, a Bóg mówi do dzieci (Św. Starzec Porfiriusz, 2020, s. 255). Starzec dawał przykłady ze swojego doświadczenia, gdy brak presji (pouczeń, wyrzu- tów) ze strony rodziców, połączony z ich gorącą, codzienną modlitwą i postem przynosił efekt w postaci przemiany dziecka $^{15}$.

Święty Porfiriusz zwracał uwagę na to, że prawidłowo pojmowana i doświadczana religia chrześcijańska przemienia człowieka i uzdrawia go, jednak dostrzegał też niebezpieczeństwo związane z nieprawidłowym przeżywaniem religii. Przyczynę braku zrozumienia prawdy upatrywał w braku pokory i egoizmie: Wiele ,religijnych" osób jest uznawanych za nieszcześliwe, gdyż widać że sa w ztym stanie psychicznym (...) Bo jeżeli nie pojmie się sensu religii $i$ nie doświadczy jej głębi, religia kończy się choroba i to $w$ dodatku straszna (...) Niektórzy z takich ludzi, praktykując religię przeżywaja swoiste piekło. Najważniejszym warunkiem wstępnym, by poznać prawdę i odróżnić ja od fatszu, jest jednak pokora. Egoizm zaciemnia umyst cztowieka, otumania go, prowadzi go do iluzji duchowej, do herezji (Św. Starzec Porfiriusz, 2020, s. 127).

Przenosząc tę myśl na wychowanie dzieci, Starzec zauważał, że egoistyczne pobudki rodziców, nawet w odniesieniu do sfery religii, przynoszą efekt odwrotny od zamierzonego: Przyczyna, dla której dzieci niektórych pobożnych rodziców buntuja się, gdy dorastaja, zostawiaja Cerkiew $i$ wszystko, co z tym jest zwiazane, i gdzie indziej szukaja zaspokojenia, jest wtaśnie ta presja, która wywieraja ,,dobrzy” rodzice. Ci jakoby „pobożni” rodzice, których staraniem było zrobienie z dzieci ,dobrych chrześcijan”, swoja ludzka mitościa przyttoczyli dzieci i stato się dokładnie na odwrót (Św. Starzec Porfiriusz, 2020, s. 257). Wychowanie religijne nie oznacza zatem jedynie formalnego uczestniczenia w życiu liturgicznym oraz nauczenia dzieci religijnych formułek i zewnętrznych form zachowania, ale danie wychowania w Panu [Ef 6,4], czyli bycia świętym i przekazania tego swojemu dziecku. Na tym właśnie polega sekret: badź dobry, badź święty, żebyś tym promieniowat i inspirowat innych. Jeżeli będzie się to dziato, gdy dziecko będzie jeszcze małe, nie będzie musiało się wiele natrudzić, gdy dorośnie. (...) Jeżeli rodzice sa święci i przekaża to dziecku, wówczas dziecko, jakich by nie doznawało ztych wplywów ze strony otoczenia, nie ulegnie, bo tuż za jego drzwiami będzie stat Chrystus (Św. Starzec Porfiriusz, 2020, s. 257).

Kolejnym elementem, na który zwraca uwagę Starzec, jest zdobycie pokory i przekazanie tego dzieciom. Najważniejszym warunkiem wstępnym, by poznać prawdę i odróżnić ja od fatszu, jest pokora ${ }^{16}$. W rozwoju dzieci lekarstwem i jednocześnie wielkim sekretem jest pokora (Św. Starzec Porfiriusz, 2020, s. 260). Pokora jest w literaturze ascetycznej uznawana za początek drogi duchowej i główny warunek do wyzwolenia się namiętności ${ }^{17}$, zatem skoro nie chcemy przekazać dzieciom zła, które w sobie nosimy, należy ćwiczyć w tej cnocie przede wszystkim siebie samych, a także swoje dzieci. Pan chce, abyśmy poprowadzili dzieci do pokory. Trzeba uważać, jak dodaje się śmiato-

\footnotetext{
15 Zob. Świety Starzec Porfiriusz (2020), s. 252-254.

16 Święty Starzec Porfiriusz (2020), s. 127.

17 Zob. św. Jan Klimak, Drabina raju (2011), 709D, 71, s. 137.
} 
ści dzieciom. Nie powinno się mówić: „,Tobie to się udało! Ale ty jesteś madry! Ty to jesteś odważny! Jesteś doskonaty!...". Nie pomagacie dziecku w ten sposób (...) Powiedzcie: „Synku, zdolności, które posiadasz, dat ci Bóg. Módl się, żeby Bóg dat ci też siłę, żebyś mógt je rozwijać i żebyś osiagnat sukces. Niech Bóg da ci swoja taskę"(...) Niech dzieci naucza się we wszystkich sprawach prosić o pomoc Boża (Św. Starzec Porfiriusz, 2020, s. 260). Starzec upatruje w egoizmie przyczynę odejścia od Boga człowieka w każdym wieku. Brak pokory, egoizm jest według niego na tyle obcy ontologicznie człowiekowi, że utożsamia go z apostazją z chrześcijaństwa. Egoizm to wielkie zło - wyprowadzit czlowieka z Raju (...) Naturalnym stanem czlowieka, takim, w którym stworzyt go Bóg, jest pokora. Zaś egoizm jest czymś nienaturalnym, jest choroba, czymś przeciwnym naturze (Św. Starzec Porfiriusz, 2020, s. 263). Sposobem, w który rodzice przekazują swoim dzieciom egoizm, są, zdaniem Starca, nadmierne pochwały: Dzieci, gdy je ciagle nierozważnie chwalimy, nieprzyjaciel coraz bardziej wbija w pychę (...) Wyrosna na egoistów, a nie na chrześcijan. Egoiści nigdy nie moga być chrześcijanami (...) Gdy dzieci nieco podrastaja i z tym egoizmem ida do szkoty, odchodza od religii i gardza nia, traca szacunek do Boga, do rodziców, do wszystkiego. Buntuja się, staja się okrutne i nieczułe, nie szanuja ani religii, ani Boga. Wypuściliśmy na świat egoistów, a nie chrześcijan (Św. Starzec Porfiriusz, 2020, s. 261). Gdy pochwatami budujemy $w$ dziecku owe ,superego", wbijamy je w pyche, wyrzadzamy mu wielka krzywdę (...) oddalamy je od wszystkich wartości życiowych (Św. Starzec Porfiriusz, 2020, s. 263).

Starzec zdaje sobie sprawę z tego, że ogólnie przyjęte w społeczeństwie zasady w braku pochwał widzą wpędzanie dziecka w kompleksy lub odbieranie mu motywacji. Jednak komukolwiek o tym powiesz, ustyszysz: „O czym ty mówisz, człowieku? Jeśli nie będziesz chwalit dziecka, to nie będzie się mogło uczyć..." (Św. Starzec Porfiriusz, 2020, s. 263). Mentalność wspótczesnego spoteczeństwa wyrzadza dzieciom zło. Zawiera w sobie inna psychologie, inna pedagogike, które sa adresowane do ludzi niewierzacych. Ta mentalność prowadzi do samowoli. A efekty widzicie wśród dzieci i młodzieży (Św. Starzec Porfiriusz, 2020, s. 264). Warto podkreślić, że święty nie był zwolennikiem ,zimnego chowu”, wychowania opartego na braku okazywania pozytywnych uczuć. Wynika to jasno z jego opinii na temat wywierania presji na dzieciach. Brak pozytywnych uczuć, brak troski o dziecko wyrażanej w modlitwie za nie, jest brakiem wychowania w ogóle i nigdzie nie znajdujemy takiego zalecenia w nauczaniu Starca. Kwestię dyscyplinowania dzieci święty odnosi właśnie do kwestii zdobywania pokory i daje następującą interpretację słynnego cytatu z ksiąg dydaktycznych Starego Testamentu: Tak samo i dziecku powiedz prawdę, huknij na nie, żeby zorientowato się, że to co robi, nie jest dobre. Co mówi madry Salomon? „Nie kocha syna, kto rózgi żałuje, kto kocha go - w pore go karci [Prz 13,24]. Nie oznacza to, że masz je bić kijem. W takim przypadku przekraczamy granice i efekt jest odwrotny do zamierzonego (Św. Starzec Porfiriusz, 2020, s. 261). Mimo wszystko Starzec zaleca zastąpienie środków przymusu modlitwą: Gdy dzieci sq niegrzeczne, stosujcie środki wychowawcze, ale nie wywierajcie na nie presji. Przede wszystkim się módlcie. Często rodzice rania swoje dziecko, z powodu bałaganu, który narobiło i besztaja je przesadnie. Takie coś je rani (Św. Starzec Porfiriusz, 2020, s. 249).

Zgodnie ze świadectwem osób, które miały okazję dobrze go poznać osobiście, Starzec wierzył w to, że najważniejszym wsparciem i pomocą, które można ofiarować bliźniemu, jest wysłuchaniu go w momencie, gdy musi on porozmawiać o swoich potrzebach i problemach, gdy chce wyrazić swój ból, gdy potrzebuje naszego wsparcia, nawet tylko towarzystwa, aby nie czuć przytłaczającej samotności i społecznego odrzucenia, które niszczy osobowość

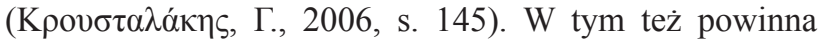
zawierać się rola rodziców, którzy powinni być w stanie zatrzymać się i nie tylko wysłuchać, ale poprzez modlitwę i działanie łaski Bożej autentycznie pomóc swojemu dziecku. Dziecko ma wewnętrzny problem i dlatego źle się zachowuje. Nie poprawi tego dzięki logice, nie można go przekonać stowami lub zmusić groźbą. Aby się uwolnić potrzebuje świętego człowieka, człowieka wielkiej miłości, który nie będzie go pouczat, straszyt, ale będzie żyt w świętości. I dziecko, widzac to, pozazdrości takiego życia i zacznie go naśladować (Św. Starzec Porfiriusz, 2020, s. 250). Wykształcenie rodziców, jak również edukacja szkolna dziecka, zdaniem Starca nie daje żadnej gwarancji prawidłowego rozwoju i nie powinna być celem samym w sobie. Widzicie, jakie rzeczy przeżywaja niektórzy rodzice ze swoimi dziećmi? (...) Kochali je milościa ludzka, ale też wywierali na nie presję, nie mając w sobie dość świętości, by przyprowadzić je do Chrystusa. (...) Mogli nawet mieć świetne wyksztatcenie, wiedze psychologiczna $i$ przygotowanie naukowe, a mimo to stracili swoje dzieci. Co ci da wykształcenie? Tylko taska Boża, tylko prawdziwa milość (...) może zbawić zarówno innych, jak i nas samych (Św. Starzec Porfiriusz, 2020, s. 251).

Dostrzec w tym można podobieństwo do założeń, mało jeszcze w Polsce znanej, edukacji spersonalizowanej, która przenosi ciężar $\mathrm{z}$ wykształcenia na tutoring rodziców oraz na stworzenie dziecku możliwości do odkrycia kierunku, w którym powinno się rozwijać poprzez relację $\mathrm{z}$ drugą osobą ${ }^{18}$. Pozwól dziecku, by same zainteresowato się swoim rozwojem. Wtedy ci się uda (Św. Starzec Porfiriusz, 2020, s. 251).

$$
* * *
$$

W myśli pedagogicznej świętego Porfiriusza można wyodrębnić następujące główne elementy nauczania: uświadomienie i prawidłowe zrozumienie przez rodziców celu życia jako upodobniania się do Boga - stawania się świętym z łaski Bożej (aspekt soteriologiczny), zamiana presji wy-

\footnotetext{
18 „Edukacja spersonalizowana daje jej uczestnikom szansę na zaspokojenie głodu poznawczego, na autoedukację w dialogu, nieustanny rozwój i, co więcej, najcenniejszą wartość dodaną - indywidualny, poznawczo stymulujący kontakt z drugim człowiekiem, który słucha" Karpińska -Musiał, B. (2016), Edukacja spersonalizowana w uniwersytecie, Kraków, s. 20.
} 
wieranej na dzieci (dostrzeganej też w nadopiekuńczości) na modlitwę za nie (aspekt ascetyczny), walka z egoizmem poprzez unikanie nadmiernych pochwał i zdobywanie pokory przez przypisywanie zasługi nie dziecku, lecz łasce Bożej. Dyscyplina i środki wychowawcze mogą być stosowane, ale z umiarem i bez chęci wywierania presji.

Rola modlitwy i podejście do jej praktykowania przez ustawienie w centrum miłości Bożej wpisuje się w prawosławną tradycję ascetyczną, kojarzoną przede wszystkim $\mathrm{z}$ autorem podręcznika życia duchowego, św. Janem Klimakiem oraz św. Maksymem Wyznawcą ${ }^{19}$, natomiast podejście do zdobywania pokory i walki z egoizmem zawiera podobne elementy do nauczania innego współczesnego Starca,

19 św. Jan Klimak, Drabina raju, Kęty 2011, s. 79. św. Paisjusza Hagioryty. Pogłębionych badań wymaga eklezjologia chrystocentryczna św. Porfiriusza, a szczególnie pojęcie „niestworzonej, ziemskiej Cerkwi”, które zawiera w sobie pewną antynomię wymagającą dokładniejszego przestudiowania. Kolejnym wartym uwagi tematem do badań jest rola modlitwy, a zwłaszcza podejście Starca do praktykowania modlitwy Jezusowej i hezychazmu.

Myśl pedagogiczna św. Porfiriusza jest przepełniona pokorną i pełną miłości troską o zbawienie drugiego człowieka, co charakteryzowało jego osobę nie tylko w nauczaniu, ale i w życiu codziennym. Charyzmaty, które posiadał oraz liczne cudowne wydarzenia tylko potwierdzają, że powyższe zalecenia są nie tylko zgodne z tradycją prawosławną, ale i skuteczne dla każdego człowieka, który decyduje się je realizować w swoim życiu.

\section{Bibliografia}

Atanazy, metr. (2016). Otwarte serce cerkwi. (K. Tur, Tłum.). Hajnówka: Bratczyk.

Bóg i zło. Pisma Bazylego Wielkiego, Grzegorza z Nyssy i Jana Chryzostoma. (2004). (ks. J. Naumowicz, red.). Kraków: Wydawnictwo M.

Chatzinikolaou, N. (2013). Tam gdzie nie widać Boga. (s. E. Niczyporuk, Tłum.). Zaleszany: Żeński Dom Zakonny w Zaleszanach.

Karpińska-Musiał, B. (2016). Edukacja spersonalizowana w uniwersytecie. Kraków: Wydawnictwo Libron.

Larchet, J-C. (2013). Terapia chorób duchowych. Wstęp do tradycji ascetycznej Kościoła prawosławnego. (s. N. Aleksiejuk, Tłum.). Hajnówka: Bratczyk.

Łosski, W. (1989). Teologia mistyczna Kościoła wschodniego. (M. Sczaniecka, Tłum.). Warszawa: Instytut wydawniczy PAX.

Meyendorff, J. (1984). Teologia bizantyjska. (J. Prokopiuk, Tłum.). Warszawa: Instytut wydawniczy PAX.

Jan Klimak, św. (2011) Drabina raju. (W. Polanowski, E. Osek, Tłum.). Kęty: Wydawnictwo Marek Derewiecki.

Święty Starzec Porfiriusz Kavsokalybita - O dzieciach i młodziezy. (2016). (K. Tur, J. Szokalski, Tłum.). Hajnówka: Bratczyk.

Święty Starzec Porfiriusz z Kafsokaliwii, Żywot i słowa. (2020). (G. Makal, Tłum.). Białystok: Stowarzyszenie Prawosławne Bractwo św. św. Cyryla i Metodego. św. Symeon Nowy Teolog. Sources Chrétiennes 129. (1967). Paris.

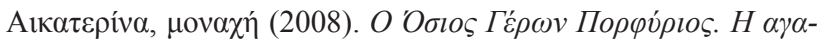
$\pi \omega ́ \sigma \alpha \kappa \alpha \rho \delta i \alpha$. A $\theta \dot{v} v \alpha$.

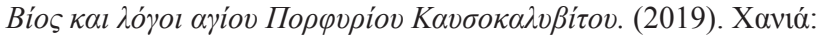

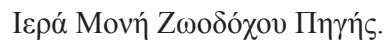

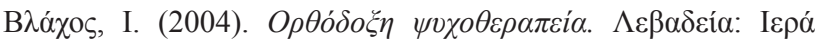

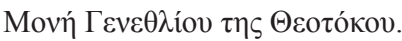

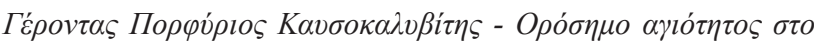

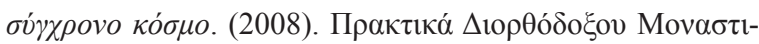

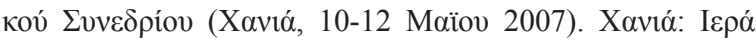
Moví Z

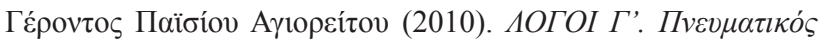

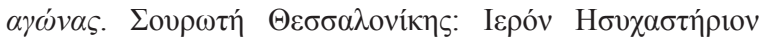

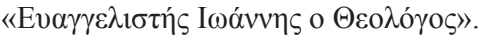

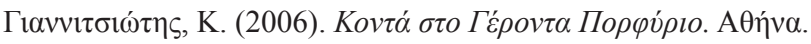

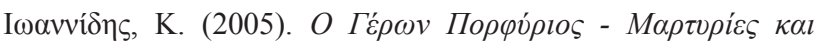

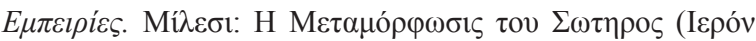

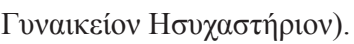

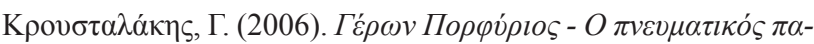

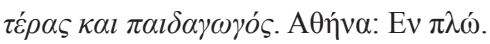

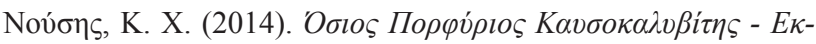

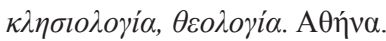

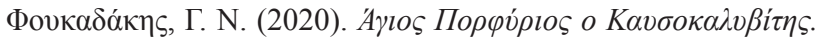

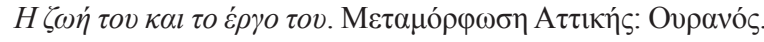

Rozmiar artykułu: 0,9 arkusza wydawniczego 